\title{
KINETICS STUDIES OF FUNGAL BIOGAS PRODUCTION FROM CERTAIN AGRICULTURAL WASTE
}

\author{
Bishir, U. * and M. M. Ekwenchi** \\ *Department of Pure and Industrial Chemistry, Bayero University, Kano, Nigeria \\ **Department of Chemistry University of Jos, Jos, Plateau State, Nigeria \\ Correspondence author: bishirbum@yahoo.com
}

\begin{abstract}
Anaerobic degradation of sugar cane and rice husk by cellulolytic fungus was studied respectively at optimum operational condition of concentration, 1:5 w/v of the lignocelluloses: water and temperature of $33^{\circ} \mathrm{C}$. The average rates of biogas production determined for sugar cane and rice husk were $57 \mathrm{~cm}^{3}$ per day and $47 \mathrm{~cm}^{3}$ per day, while the yield of biogas evaluated appear to be high, $15.2 \%$ for sugar cane and $12.5 \%$ for rice husk. The yields from other agricultural wastes were lower than these values ( $0.8 \%$ cow dung - $11.6 \%$ water hyacinth). The compositional yields of the biogas were also assessed; $5.7 \% \mathrm{CH}_{4}, 8.3 \% \mathrm{CO}_{2}$, and $1.2 \% \mathrm{H}_{2} \mathrm{~S}$ for sugar cane and $4.9 \% \mathrm{CH}_{4}$, $6.1 \% \mathrm{CO}_{2}$ and $1.5 \% \mathrm{H}_{2} \mathrm{~S}$ for rice husk. Results have shown that the biogas of rice husk is of better quality than that of sugar cane because of its lower content of $\mathrm{CO}_{2}$. It was also found that when the amount of the substrates were respectively doubled, the average rate of the biogas production doubled, implying that kinetically, the degradation is probably first order. The yield of the bioliquid for sugar cane was determined as $94 \%$ and rice husk was $68 \%$.
\end{abstract}

Key word: Biogas, Fungal Degradation, Bioliquid, Rice Husk, Sugarcane.

\section{INTRODUCTION}

The socio-economic development of a country largely depends on the availability and consumption of energy. The available sources of energy can be classified into two categories, renewable and nonrenewable energy sources. The non-renewable energy sources which are also called fossil fuels are finite deposits of coal, natural gas, uranium and deuterium. The renewable sources of energy are photosynthetic materials, solar, hydroelectric and tidal energies. Renewable energy is deposited every day, whereas the non-renewable is continuously depleted by our withdrawals resulting from continual depletion in the natural resources and by an increased consumption of the energy alternatives of fossil fuels has to be searched out. Therefore, bioenergy could be the only alternative and cheap sources of energy which can be made available to the rural areas. (Shoeb and Singh, 2000)

The term biogas system is somewhat of a misnomer though biogas system is often viewed as an energy supply technology. Chinese regard their systems primarily a means to provide fertilizer and the sanitary disposal of organic residue, gas is considered as useful by-product (Richard et al., 1994). In India interest in biogas is due to its potential as fuel substitute for firewood, dung, kerosene, agricultural residues, diesel, and petroleum and electricity, depending on the particular task to be performed and on local supply and price constraints. Therefore biogas typically refers to biofuel. The gas is produced by anaerobic digestion or fermentation of organic matter, as well as manure, sewage sludge, municipal solid waste, or any other biodegradable feed stock under anaerobic condition (Richard et al., 1994). Biogas comprised primarily of methane $(60-70 \%)$ and carbon dioxide (30-40\%) depending on the material used. Biogas can also be called swamp gas, marsh gas, landfill gas, digester gas (Shoeb and Singh, 2000).

Biogas is a naturally occurring emission of bacteria that thrive without oxygen that occurs in three steps. First is the decomposition or hydrolysis of biodegradable material into molecules such as sugars. Next these molecules are converted into acid. Lastly the acids are converted into biogas. Anaerobic digestion harnesses the bacteria in its natural process in order to capture and utilize the biogas, all in a safer controlled environment.

Biogas produced in anaerobic digester is burned to generate clean renewable energy. released in uncombusted form is harmful to the environment (Prasad, 1974).

Biogas system provides three products; energy, fertilizer and waste residue, the term biogas system in this study will refer to the technology of digesting organic waste anaerobically to produce an excellent fertilizer and combustible gas and to disposing agricultural residues, aquatic weeds, animal and human excrement and other organic matter (Prasad, 1974).

This research is aimed at maximizing yield of biogas at optimal conditions. The objective of the research is to guarantee that the biogas can be reasonably produced at reproducible rate and also at a profitable and efficient rate using sugarcane (barck and pulp) and rice husk. 


\section{MATERIALS AND METHODS \\ Sample Collection and Processing}

The experimental fungal degradation of lignocelluloses from sugarcane (barck and pulp) and rice husks at optimum condition to produce biogas was carried out in an anaerobic condition and the procedures with all the material, apparatus and reagent used are outlined below.

The fresh sugarcane (Substrate) was collected from Karfi, in Malumfashi district Katsina State and the rice husk (substrate) was collected from a farm in Kura, Kura Local Government Council, Kano State. The sugarcane bark was removed and pulp was pressed removed the juices. The rice husks were removed from fresh rice and both of these samples were dried in an oven at a temperature of $40^{\circ} \mathrm{C}$ for about 48 hours. The oven dried sugarcane and rice husk was grinded to fine powder using mortar and pestle and subsequently sieved with a sieve of mesh size (100 microns). The powdered substrates were stored in reagent bottles and kept away from sunlight and moisture.

\section{Generation of Biogas}

Four sets of $250 \mathrm{~cm}^{3}$ round bottom flask digesters were used for the generation of the biogas. The digesters were properly stoppered in order to avoid leakages. Each digester contained sugar cane or rice husk, yeast (fungus) and water in order to produce the necessary biogas required in the respective experiment.
Keeping the amounts $(4 \mathrm{~g})$ of lignocellulose and yeast $(0.06 \mathrm{~g})$ constant, the amount of water was varied in the range of $15,20,25$ and $30 \mathrm{~cm}^{3}$ in order to find out the amount of water required to produce the optimum yield of biogas. Next, the amounts of lignocellulose $(4 \mathrm{~g})$ and water $\left(25 \mathrm{~cm}^{3}\right)$ were kept constant and the amount of yeast was varied in the range of $0.06 \mathrm{~g}$, $0.12,0.18$ and $2.40 \mathrm{~g}$ in order to establish the amount of yeast to produce the optimum yield of biogas. After obtaining the required amounts of water and yeast with the known amount of lignocellulose used in producing the biogas at a known temperature, next set of experiment involved varying the temperature in the range of $28,33,36$, and $40^{\circ} \mathrm{C}$ while keeping the amounts of lignocellulose $(4 \mathrm{~g})$, water $\left(25 \mathrm{~cm}^{3}\right)$ and yeast $(0.12 \mathrm{~g})$ constant. In this set of experiment involves the digesters $A, B$, and $C$ for the Compositional analysis of biogas generated for sugarcane as.

A: $8 \mathrm{~g}$ of sugar cane $+50 \mathrm{~cm}^{3} \mathrm{H}_{2} \mathrm{O}+0.24 \mathrm{~g}$ fungus. Biogas passed through $\mathrm{H}_{2} \mathrm{O}$ (gas collected $\mathrm{CH}_{4}+\mathrm{CO}_{2}+\mathrm{H}_{2} \mathrm{~S}$ )

B: $8 \mathrm{~g}$ of sugar cane $+50 \mathrm{~cm}^{3} \mathrm{H}_{2} \mathrm{O}+0.24 \mathrm{~g}$ fungus. Biogas passed through $1 \mathrm{M} \mathrm{NaOH}$ (gas collected $\mathrm{CH}_{4}+\mathrm{H}_{2} \mathrm{~S}$ )

C: $8 \mathrm{~g}$ of sugar cane $+50 \mathrm{~cm}^{3} \mathrm{H}_{2} \mathrm{O}+0.24 \mathrm{~g}$ fungus. Biogas passed through lead acetate solution (gas collected $=\mathrm{CH}_{4}+\mathrm{CO}_{2}$ ).

Similarly in table 2 the digesters $A, B$ and $C$ for the Compositional Analysis of biogas generated from Rice husk as

A: $8 \mathrm{~g}$ of rice husk $+50 \mathrm{~cm}^{3} \mathrm{H}_{2} \mathrm{O}+0.24 \mathrm{~g}$ fungus. Biogas passed through $\mathrm{H}_{2} \mathrm{O}$

$\mathrm{B}: 8 \mathrm{~g}$ of rice husk $+50 \mathrm{~cm}^{3} \mathrm{H}_{2} \mathrm{O}+0.24 \mathrm{~g}$ fungus. Biogas passed through $1 \mathrm{M} \mathrm{NaOH}$

C: $8 \mathrm{~g}$ of rice husk $+50 \mathrm{~cm}^{3} \mathrm{H}_{2} \mathrm{O}+0.24 \mathrm{~g}$ fungus. Biogas passed through lead acetate solution (gas collected = $\left.\mathrm{CH}_{4}+\mathrm{CO}_{2}\right)$

In each case at the end of biogas production, the $\mathrm{pH}$ of the digester content was taken, and the content was also dried appropriately to constant weight, then the dried content was exhaustively extracted with soxhlet extractor for 74 hours in order to obtain the liquid component of the residue left in the round bottom flask (bioliquid), using the rotor evaporator. The extract was dried to constant weight by obtaining its weight.

\section{Effect of lignocelluses, water and yeast on yield of Biogas}

In the next set of experiments, the amounts of lignocelluloses, water and yeast were doubled in order to see its effect on the yield of biogas.Proper set-ups were done in this work to separate the biogas into $\mathrm{CH}_{4}, \mathrm{CO}_{2}$ and $\mathrm{H}_{2} \mathrm{~S}$ using appropriate reagents, $\mathrm{NaOH}$, which will dissolve $\mathrm{CO}_{2}$ and $\mathrm{Pb}\left(\mathrm{CH}_{3} \mathrm{COO}\right)_{2}$, which will remove $\mathrm{H}_{2} \mathrm{~S}$ as a precipitate of $\mathrm{PbS}$. By the arrangement the respective amounts of $\mathrm{CH}_{4}, \mathrm{CO}_{2}$ and $\mathrm{H}_{2} \mathrm{~S}$ in the biogas produced could assess. The reactions involved in the separation are as follows, and the volume of biogas and its component was collected by upward delivery.

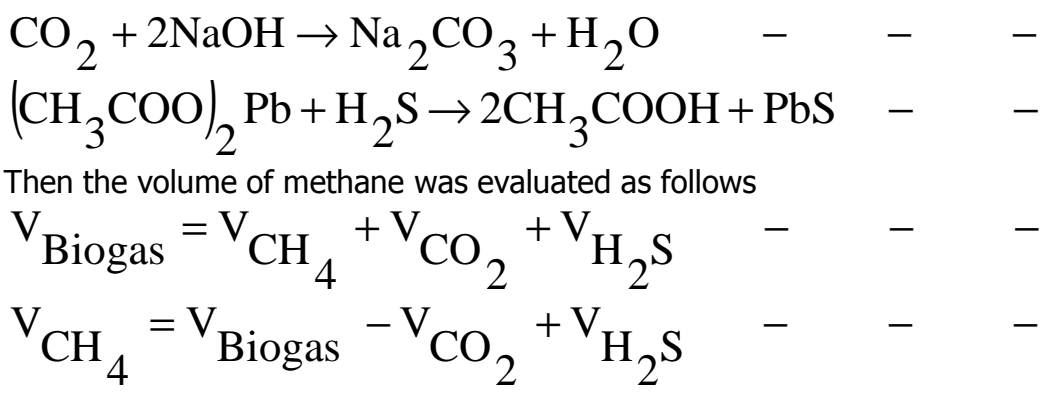


Bajopas Volume 5 Number 2 December, 2012

$$
\begin{aligned}
& \mathrm{V}_{\mathrm{CO}_{2}}=\mathrm{V}_{\text {Biogas }}-\mathrm{V}_{\mathrm{H}_{2}} \mathrm{~S} \\
& \text { Where } \\
& \mathrm{V}_{\text {Biogas }}, \mathrm{V}_{\mathrm{CH}_{4}}, \mathrm{~V}_{\mathrm{CO}_{2}}, \mathrm{~V}_{\mathrm{H}_{2} \mathrm{~S}} \text { are the respective volume of biogas, } \mathrm{CH}_{4}, \mathrm{CO}_{2} \text { and } \mathrm{H}_{2} \mathrm{~S} \text {, the }
\end{aligned}
$$
percentage composition of the gas generated was evaluated as follows.

$$
\begin{aligned}
& \mathrm{CH}_{4} \%=\frac{\mathrm{V}_{\mathrm{CH}_{4}}}{\mathrm{~V}_{\text {Biogas }}} \times 100 \quad-\quad-\quad-\quad \ldots \\
& \mathrm{CO}_{2} \%=\frac{\mathrm{V}_{\mathrm{CO}_{2}}}{\mathrm{~V}_{\text {Biogas }}} \times 100 \quad-\quad-\quad-\quad \text { (7) } \\
& \mathrm{H}_{2} \mathrm{~S} \%=\frac{\mathrm{V}_{\mathrm{H}_{2} \mathrm{~S}}}{\mathrm{~V}_{\text {Biogas }}} \times 100 \quad-\quad-\quad-\quad-\quad \text { (8) }
\end{aligned}
$$

(Ekwenchi et al., 1989)

The same procedure was applied to rice husk.

\section{RESULTS AND DISCUSSION}

The results of the respective compositional analysis of the biogas yields for both sugar cane and rice husk are shown in Table 1 and Table 2 respectively. Sample A comprised a mixture of $\mathrm{CH}_{4}, \mathrm{CO}_{2}$ and $\mathrm{H}_{2} \mathrm{~S}$. Sample B comprised a mixture of $\mathrm{CH}_{4}$ and $\mathrm{H}_{2} \mathrm{~S}$, while. Sample $\mathrm{C}$ comprised a mixture of $\mathrm{CH}_{4}$ and $\mathrm{CO}_{2}$.

By appropriate treatment of these biogas yields, the compositional amounts of $\mathrm{CH}_{4}, \mathrm{CO}_{2}$ and $\mathrm{H}_{2} \mathrm{~S}$ were determined. The results obtained for the respective different amounts of $\mathrm{CH}_{4}, \mathrm{CO}_{2}$ and $\mathrm{H}_{2} \mathrm{~S}$ are shown in Table 3 . These results indicated that the biogas from rice husk was of a better quality than that of sugarcane because of lower $\mathrm{CO}_{2}$ content found in the biogas from rice husk. The results of the conversion efficiency of the respective biogas and the components in the biogas evaluated, from the compositional analysis results, as well as, utilizing the general gas law, are shown in Table 4. The conversion efficiency results had shown that sugarcane produced more $\mathrm{CH}_{4}$ than rice husk, however, the overall results still pointed to the fact that the biogas from the ricehusk is of a better quality than that of the sugar cane because of the lower $\mathrm{CO}_{2}$ content of the rice husk biogas. Comparison of the result of this study with a previous study (Ekwenchi et al., 1989) on other agricultural wastes are shown in Table 5. These results had shown that both sugar cane and rice husk have higher conversion efficiency than the other substrate. This is probably because of the compositional differences in the material utilized in the degradation. Sugarcane and rice-husk have better components that are easily accessible to the fungal degradation. The result of the bioliquid (liquid component of the residue) and biogas yields presented in Table 6 has a similar trend whereby the sugarcane produced more than rice-husk. The result of the calculated average daily rates is shown in Table 7. The results indicate that sugar cane has a higher average daily rate than rice-husk, implying that sugarcane is made up of lignocellulose better degradable than the lignocellulose of rice-husk.

From the results obtained there was evidence that energy could be renewed by using agricultural wastes in which the materials used in generating these gases were very good sources of biogas and biofuel and it can also reduce the over dependences on non-renewable source of energy. It also prevents environmental pollution there by making environment to be eco-friendly. 
Bajopas Volume 5 Number 2 December, 2012

Table 1: Compositional analysis of biogas generated for sugarcane.

\begin{tabular}{cccc}
\hline $\begin{array}{c}\text { Time } \\
\text { (Days) }\end{array}$ & A & Volume of Biogas Generated $\left(\mathbf{c m}^{\mathbf{3}} \mathbf{)}\right.$ & C \\
\hline 1 & 0 & $\mathbf{B}$ & 60 \\
2 & 230 & 20 & 80 \\
3 & 230 & 60 & 100 \\
4 & 240 & 80 & 120 \\
5 & 250 & 110 & 120 \\
6 & 300 & 180 & 120 \\
7 & 390 & 260 & 140 \\
8 & 460 & 340 & 180 \\
9 & 560 & 520 & 220 \\
10 & 680 & 590 & 240 \\
11 & 740 & 620 & 280 \\
12 & 810 & 690 & 320 \\
13 & 870 & 710 & 490 \\
14 & 920 & 710 & 560 \\
15 & 960 & 710 & 780 \\
16 & 1040 & 710 & 840 \\
17 & 1110 & 710 & 930 \\
18 & 1170 & 710 & 1020 \\
19 & 1170 & 710 & 1040 \\
20 & 1170 & 710 & 1095 \\
\hline
\end{tabular}

Table 2: Compositional Analysis of biogas generated from Rice husk. Cumulative volume of biogas generated $\left(\mathrm{cm}^{3}\right)$

\begin{tabular}{|c|c|c|c|}
\hline \multirow{2}{*}{$\begin{array}{l}\text { Time } \\
\text { Day }\end{array}$} & \multicolumn{2}{|c|}{ Volume of Biogas Generated $\left(\mathrm{cm}^{3}\right)$} & \multirow[b]{2}{*}{ C } \\
\hline & $\mathbf{A}$ & B & \\
\hline 1 & 30 & 50 & 100 \\
\hline 2 & 60 & 50 & 140 \\
\hline 3 & 140 & 100 & 180 \\
\hline 4 & 180 & 100 & 240 \\
\hline 5 & 180 & 190 & 280 \\
\hline 6 & 200 & 230 & 320 \\
\hline 7 & 220 & 290 & 360 \\
\hline 8 & 230 & 320 & 440 \\
\hline 9 & 260 & 390 & 480 \\
\hline 10 & 280 & 450 & 520 \\
\hline 11 & 280 & 480 & 630 \\
\hline 12 & 290 & 560 & 745 \\
\hline 13 & 300 & 630 & 830 \\
\hline 14 & 305 & 630 & 890 \\
\hline 15 & 380 & 710 & 890 \\
\hline 16 & 490 & 710 & 890 \\
\hline 17 & 520 & 710 & 890 \\
\hline 18 & 530 & & \\
\hline 19 & 560 & & \\
\hline 20 & 570 & & \\
\hline 21 & 570 & & \\
\hline 22 & 650 & & \\
\hline 23 & 780 & & \\
\hline 24 & 840 & & \\
\hline 25 & 890 & & \\
\hline 26 & 960 & & \\
\hline 27 & 990 & & \\
\hline
\end{tabular}

Table 3: Composition of the biogas

\begin{tabular}{lllc}
\hline Material & \multicolumn{2}{c}{ Yields in \% } \\
\cline { 2 - 4 } Sugar cane & $\mathrm{CH}_{4}$ & $\mathrm{CO}_{2}$ & $\mathrm{H}_{2} \mathrm{~S}$ \\
Rice husk & 61.1 & 32.5 & 6.4 \\
\hline
\end{tabular}


Bajopas Volume 5 Number 2 December, 2012

Table 4: Conversion efficiency in \%

\begin{tabular}{lllll}
\hline Material & Biogas & $\mathrm{CH}_{4}$ & $\mathrm{CO}_{2}$ & $\mathrm{H}_{2} \mathrm{~S}$ \\
\hline Sugar cane & 15.2 & 5.7 & 8.3 & 1.2 \\
Rice husk & 12.5 & 4.9 & 6.1 & 1.5 \\
\hline
\end{tabular}

Comparison to other sources of agricultural wastes

Table 5: Conversion efficiencies of biogas in \%

\begin{tabular}{lll}
\hline Material & \% Biogas & Reference \\
\hline Sugar cane & 15.2 & This work \\
Rice husk & 12.5 & This work \\
Cow dung & 0.8 & ${ }^{*}$ Previous work \\
Water hyacinth & 11.6 & ${ }^{*}$ Previous work \\
Maize & 9.9 & ${ }^{*}$ Previous work \\
Maize stalks & 9.3 & ${ }^{*}$ Previous work \\
Elephant grass & 3.4 & 'Previous work \\
\hline \multicolumn{2}{c}{${ }^{*}$ Ekwenchi et al., 1989} &
\end{tabular}

Table 6: Biogas average daily rate in $\mathrm{cm}^{3}$ per day

\begin{tabular}{lll}
\hline Material & $4 \mathrm{~g}$ substrate & $8 \mathrm{~g}$ substrate \\
\hline Sugar cane & 5.7 & 11.2 \\
Rice husk & 4.7 & 9.2 \\
\hline
\end{tabular}

Table 7: Bioliquid and Biogas Yield

\begin{tabular}{lll}
\hline Material & Bioliquid yield in \% & Biogas Yield $\mathrm{cm}^{3}$ \\
\hline Sugar cane & 94 & 1200 \\
Rice husk & 68 & 990 \\
\hline
\end{tabular}

\section{REFERENCES}

Ekwenchi, M. M., Basil, U. A., Okeke, N. R. and Ekpiyong, I.(1989). Gaseous Fuel Production from fungal lignocelluloses degradation, publish by Journal of science direct (6):15691572.

Garba, B. (1990). Studies on the chemical composition of Biogas and Kinetics of its Production at Varying Temperature. PHD Thesis, Department of Pure and Applied Chemistry Usman Danfodiyo, University, Sokoto, Nigeria

Prasad, C.R, Prasad, K.K. and Reddy, A. K. N. (1974), Biogas plants, prospects and
Problems tasks. The economy and political weekly. http://sleekfreak.ath.cx:81/3wdev/VITAHML/ SUBLEV/EN1/BIOGASIN.HTM

Richards, B. (1994). "In situ methane enrichment in methanogenic energy crop digesters". Journal of Biomass and Bioenergy 6: 275274.

Shoeb, F. and Singh, H. J. (2000), kinetics studies of Biogas evolved from water hyacinth. A paper presented at $2^{\text {nd }}$ international Symposium on New Technological for Environmental Monitoring and Agro applications. www.greentrust.org/2000/biofuels/kineticsst udies.htm 